\title{
Perancangan dan Pengembangan Sistem Electrospinning sebagai Teknologi dalam Pembuatan Nanofiber
}

\author{
Marno $^{1^{*}}$, Eri Widianto ${ }^{2}$, Jojo Sumarjo ${ }^{3}$, Aa Santosa ${ }^{4}$ \\ ${ }^{1-4}$ Jurusan Teknik Mesin, Fakultas Teknik, Universitas Singaperbangsa Karawang \\ *Corresponding author, e-mail: indexindocv@gmail.com
}

\begin{abstract}
Abstrak- Telah dilakukan pembuatan sistem electrospinning untuk mensintesis nanofiber. Tujuan dari penelitian ini adalah membuat electrospinning dengan memodifikasi syringe pump yang dapat bergerak kanan-kiri dan menggunakan collector silinder. Pengujian sistem electrospinning dilakukan dalam pembuatan nanofiber Polivinil Alkohol (PVA) 10\%. Struktur dan morfologi nanofiber PVA dikarakterisasi menggunakan Scanning Electron Microscopy (SEM). Hasil SEM menunjukkan bahwa nanofiber PVA relatif seragam dengan ukuran diameter rata-rata $(147,85 \pm 24,73) \mathrm{nm}$. Hasil nanofiber pada penelitian ini diharapkan dapat digunakan diberbagai aplikasi.
\end{abstract}

Kata kunci： Electrospinning, Nanofiber, PVA, SEM

Abstract-Fabrication of electrospinning system to synthesis nanofiber have been done. The purpose of this research is to fabricated electrospinning by modifying the syringe pump that can move right-left and using drum collector. Electrospinning system testing is done by making 10\% Polyvinyl Alcohol (PVA) nanofiber. The structural and morphological properties of PVA nanofiber were characterized by Scanning Electron Microscopy (SEM). The result of SEM showed that PVA nanofiber have a relatively uniform with average diameter of nanofiber size $(147.85 \pm 24.73) \mathrm{nm}$. The produced nanofiber from this research can be utilized for various application.

Keywords： Electrospinning, Nanofiber, PVA, SEM

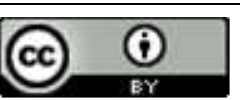

This is an open access article distributed under the Creative Commons 4.0 Attribution License, which permits unrestricted use, distribution, and reproduction in any medium, provided the original work is properly cited. C2018 by Author and Universitas Negeri Padang

\section{Pendahuluan}

Nanoteknologi terus berkembang seiring dengan perkembangan ilmu pengetahuan dan teknologi. Nanoteknologi merupakan teknologi penggunaan material dalam skala nanometer (1$100 \mathrm{~nm}$ ). Beberapa contoh nanoteknologi seperti nano partikel, nanofiber, nanowire dan nanotube. Salah satu material nano yang sampai saat ini terus diteliti dan dikembangkan adalah nanofiber, yaitu serat yang memiliki diameter antara 100-500 $\mathrm{nm}$ [1]. Nanofiber dapat diaplikasikan diberbagai bidang, seperti industri tekstil, komposit, otomotif, kertas, elektronik, optik, pertanian, kosmetik, kesehatan, kedokteran, olah raga dan farmasi [2,3]. Nanofiber dapat dibuat menggunakan sistem electrospinning.

Electrospinning merupakan salah satu metode pembentukan serat (fiber) melalui pancaran muatan listrik dari suatu larutan atau cairan polimer. Teknik ini telah dipatenkan oleh Formhals pada tahun 1934 [4]. Pada penelitian ini akan dirancang dan dibuat sistem electrospinning

dengan desain syringe pump yang dapat bergerak kanan-kiri (right-left) serta dua tipe collector yaitu plat (stand) dan drum (dapat berputar). Pengembangan sistem electrospinning dilakukan dengan menggunakan bahan baku dan komponen lokal yang ada di pasaran, khususnya di Kabupaten Karawang. Pengujian sistem electrospinning dilakukan dengan mensintesis nanofiber menggunakan polimer yang mudah diproses. Dalam penelitian ini digunakan polimer Polivinil Alkohol (PVA). Karakterisasi struktur morfologi nanofiber dilakukan menggunakan Scanning Electron Microscopy (SEM). Estimasi ukuran diameter nanofiber dilakukan menggunakan Software ImageJ. Sistem electrospinning yang telah dibuat diharapkan dapat menghasilkan nanofiber yang dapat diaplikasikan dalam berbagai bidang.

\section{Studi Pustaka}

Electrospinning pembentukan serat merupakan proses (fiber) melalui pancaran 
muatan listrik dari suatu larutan atau cairan polimer. Electrospinning merupakan teknik yang efektif dan sederhana untuk memproduksi serat (fiber) mulai dari puluhan nanometer ke mikrometer. Teknik ini telah dipatenkan oleh Formhals pada tahun 1934 [4]. Proses ini sangat sedikit digunakan dan diteliti hingga pertengahan 1990 saat Doshi dan Reneker membuat serat tipis dari berbagai polimer organik. Sejak saat itu, terjadi peningkatan penelitian baik dalam teori maupun aplikasi electrospinning. Meskipun electrospinning umumnya digunakan dalam pembuatan serat dari polimer, tetapi dapat juga digunakan dalam biologi molekul. Skema alat electrospinning dasar ditunjukkan dalam gambar berikut.

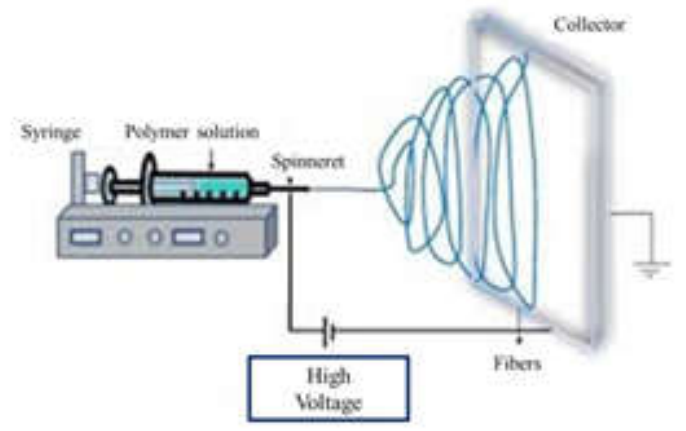

Gambar 1. Skema electrospinning [5]

Berdasarkan Gambar 1, suatu cairan polimer dimasukkan ke dalam jarum suntik kemudian ditempatkan pada syringe dengan laju konstan. Selanjutnya tegangan tinggi pada tingkat 5-30 $\mathrm{kV}$ diaplikasikan pada jarum. Larutan polimer berkembang membentuk kerucut, yang disebut dengan kerucut Taylor. Pancaran fluida dikeluarkan dan dipercepat menuju collector dasar. Ketika bergerak ke collector, pelarut menguap lalu serat mulai menipis dan menjalar sebagai akibat dari ketidakstabilan lekukan elektrostatik. Serat yang dikumpulkan biasanya sangat sedikit, ukurannya dapat bervariasi tergantung pada kondisi electrospinning yang digunakan [5].

Beberapa parameter larutan yang sangat berpengaruh dalam pembentukan serat di collector pada proses electrospinning adalah tegangan permukaan, viskositas (kekentalan), konduktivitas, dan konstanta dielektrik larutan.

\section{a. Tegangan Permukaan}

Pada proses electrospinning, muatan listrik pada larutan polimer harus cukup tinggi untuk melampaui tegangan permukaan dari larutan tersebut. Tegangan permukaan berpengaruh dalam terbentuknya manik-manik (beads) pada serat hasil electrospinning. Tegangan permukaan memiliki dampak menurunkan luas permukaan per unit massa dari sebuah zat cair. Bahan pelarut seperti ethanol yang memiliki tegangan permukaan rendah dapat ditambahkan untuk mendorong terbentuknya susunan serat yang lebih halus. Cara lainnya adalah dengan menambahkan surfactant pada larutan sehingga dapat menghasilkan serat yang lebih beragam [6].

\section{b. Viskositas dan Berat Molekul}

Viskositas dari larutan berhubungan dengan tingkat ikatan rantai molekul polimer dalam larutan. Jika viskositas larutan rendah, maka electrospraying muncul dan terbentuklah partikel polimer, bukan fiber. Jika viskositas rendah, maka ikatan rantai antar polimer rendah sehingga ada kecenderungan terbentuknya beads daripada serat yang halus. Dengan demikian, faktor yang berpengaruh pada viskositas larutan juga akan berpengaruh pada proses electrospinning dan serat yang dihasilkan. Faktor yang paling berpengaruh dalam viskositas suatu larutan adalah berat molekul polimer tersebut. Ketika suatu polimer yang memiliki berat molekul tinggi dilarutkan, viskositasnya akan lebih besar jika dibandingkan dengan polimer yang sama yang memiliki berat molekul lebih rendah.

Agar proses electrospinning menghasilkan fiber, larutan harus memiliki berat molekul dan viskositas yang cukup. Berat molekul dari suatu polimer menggambarkan panjang rantai polimer yang akan memberikan dampak pada viskositas. Salah satu cara meningkatkan viskositas larutan adalah dengan memperbesar konsentrasi larutan [6].

\section{c. Konduktivitas}

Konduktivitas bahan pelarut biasanya sangatlah kecil, berkisar antara $10^{-3}$ sampai $10^{-}$ ${ }_{9} S / m$ dikarenakan adanya beberapa ion bebas yang berpengaruh pada konduktivitas listrik larutan tersebut. Adanya asam, basa, garam, dan karbon dioksida yang terlarut dapat meningkatkan konduktivitas pelarut. Konduktivitas listrik suatu pelarut dapat ditingkatkan dengan mencampurkan bahan kimia yang tidak bereaksi. Konduktivitas larutan dapat ditingkatkan dengan menambahkan ion agar tegangan kritis berkurang sehingga electrospinning dapat terjadi [6].

Meskipun pelarut organik tidak konduktif, namun beberapa pelarut tersebut memiliki level konduktivitas tertentu. Larutan yang dibuat menggunakan pelarut dengan konduktivitas lebih 
tinggi menghasilkan serat tanpa beads. Di lain pihak, serat tidak akan terbentuk apabila konduktivitas larutan bernilai nol [6].

\section{d. Dielektrik Pelarut}

Suatu larutan yang memiliki konstanta dielektrik yang lebih tinggi akan mengurangi terbentuknya beads dan mengurangi ukuran diameter dari serat yang terbentuk. Pelarut seperti $N, N$ Dimethyl formamide (DMF) dapat ditambahkan untuk meningkatkan sifat dielektrik agar dapat meningkatkan sifat morfologi dari serat yang terbentuk [6].

\section{e. Processing Condition}

Parameter lain yang berpengaruh pada proses electrospinning adalah beberapa faktor luar yang memengaruhi kondisi electrospinning jet, diantaranya meliputi tegangan masukkan, feedrate, suhu dari larutan, dan jarak antara jarum ke kolektor. Parameter tersebut memiliki peranan berbeda dalam memengaruhi sifat morfologi dari serat yang terbentuk meskipun kurang signifikan jika dibandingkan dengan parameter larutan [6].

\section{Tegangan Masukkan}

Salah satu bagian penting dalam electrospinning adalah pemberian tegangan tinggi kepada larutan. Secara umum tegangan diatas 6 $\mathrm{kV}$ baik positif atau negatif dapat menyebabkan larutan untuk bergerak menuju ujung jarum dan membentuk taylor cone selama proses awal pembentukan jet. Tegangan yang dibutuhkan agar terbentuknya taylor cone akan meningkat bergantung pada feedrate dari larutan. Jika tegangan yang digunakan lebih besar akan menyebabkan jumlah muatan yang mendesak jet untuk bergerak lebih cepat dan lebih banyak volume dari larutan yang terbentuk pada ujung jarum. Hal tersebut dapat menghasilkan taylor cone yang lebih kecil dan kurang stabil $[6,8]$. Ketika jumlah larutan yang terbentuk pada kolektor lebih banyak dibandingkan dengan sumber, maka taylor cone akan menyusut masuk ke dalam jarum. Tegangan masukan dan medan listrik memiliki dampak pada regangan dan percepatan dari electrospinning jet, keduanya akan berpengaruh pada hasil serat yang terbentuk. Pada kebanyakan kasus, tegangan masukkan yang lebih tinggi akan meningkatkan regangan dari larutan akibat gaya coulomb yang besar pada electrospinning jet yang besarnya sama dengan besarnya medan listrik yang terbentuk [6].

\section{Feedrate}

Feedrate merupakan jumlah larutan yang bergerak melewati jarum akibat adanya dorongan pada syringe per satuan waktu. Feedrate akan berpengaruh pada jumlah ketersediaan larutan pada ujung jarum untuk melakukan proses electrospinning. Ketika feedrate dari proses electrospinning meningkat maka diameter fiber ataupun ukuran beads yang terbentuk pun akan meningkat [6].

\section{Temperature}

Suhu (temperature) dari larutan memiliki dampak dalam meningkatkan tingkat evaporasi dan menurunkan viskositas dari larutan polimer. Dengan menurunnya viskositas dari larutan polimer akibat kenaikan suhu, maka akan mengakibatkan penurunan pada diameter fiber yang terbentuk [6].

\section{Jarak antara jarum menuju kolektor}

Pada beberapa keadaan waktu tempuh dan kuat medan listrik akan berpengaruh pada proses electrospinning dan fiber yang terbentuk. Modifikasi dari jarak antara jarum dengan kolektor akan memberikan dampak pada waktu tempuh dan kuat medan listrik pada proses electrospinning. Agar fiber dapat terbentuk secara sempurna maka electrospinning jet harus memiliki waktu yang cukup untuk menuju kolektor agar pelarut dapat menguap selama proses terjadi. Ketika jarak antara jarum dan kolektor terlalu dekat maka waktu tempuh menjadi semakin sedikit sementara itu medan listrik yang dihasilkan akan semakin besar. Hal tersebut menyebabkan pelarut tidak menguap sempurna ketika telah sampai pada kolektor [6].

\section{Parameter Lingkungan}

Ada beberapa parameter lingkungan yang dapat mempengaruhi proses electrospinning. Pada tingkat kelembaban yang tinggi menyebabkan perubahan morfologi pada polimer dengan pelarut yang mudah menguap. Tipe dari udara lingkungan juga dapat mempengaruhi proses electrospinning. Setiap gas memiliki prilaku yang berbeda di bawah pengaruh medan elektrostatik. Helium akan menerobos medan elektrostatik yang ada dan dengan demikian proses electrospinning tidak akan terjadi. Sementara untuk gas yang memiliki tingkat breakdown voltage yang tinggi seperti Freon, akan mengakibatkan ukuran diameter dari fiber yang terbentuk menjadi dua kali ukuran semula. 
Selain kelembaban dan komposisi udara lingkungan, tekanan juga berpengaruh pada proses electrospinning yang terjadi. Ketika tekanan yang ada pada electrospinning jet lebih kecil dari pada yang ada pada atmosfer akan mengakibatkan kecenderungan laju dari larutan yang keluar akan menjadi tidak stabil. Pada tingkat tekanan yang sangat rendah, electrospinning tidak dapat dilakukan karena terjadi direct discharge pada muatan listrik [6].

Komponen utama electrospinning terdiri dari sumber tegangan tinggi DC (0-30 kV), Syringe Pump dan Collector. Salah satu cara mendapatkan tegangan tinggi menggunakan trafo Flyback. Pada mesin electrospinning, High Voltage DC Power Suplay merupakan sumber tegangan yang berfungsi sebagai penyupalai tegangan tinggi yang diberikan pada jarum, agar larutan menjadi bermuatan listrik dan tertarik ke arah kolektor sehingga memungkinkan terbentuknya serat. Dapat dioperasikan hingga 20 $\mathrm{kV}$ DC dengan stabil di dalamnya juga terdapat nilai yang ditampilkan pada satu $L C D$ (Liquid Crystal Display).

Rangka mesin syringe pump merupakan alat yang digunakan sebagai pendorong larutan dengan laju alir tertentu yang dapat diatur melalui controller motor dc. Syringe Pump yang dibuat menggunakan as drat dan bearing, sehingga akan meminimalisir terjadinya slip dan gesekan pada saat berputar. Selain dapat mendorong, Syrnge Pump yang dibuat juga dapat bergerak ke kanankiri. Suntikan standar yang digunakan pada Syring Pump kapasitas $5 \mathrm{ml}$. Kolektor digunakan sebagai penampung serat (fiber), jenis kolektor yang digunakan berbentuk plat plastik dengan luas penampang $130 \mathrm{~cm}^{2}$. Pada permukaan kolektor nantinya dilapisi dengan aluminiumfoil yg dihubungkan dengan kabel negative dari tegangan tinggi.

Arduino Uno R3 adalah papan pengembangan mikrokontroler yang berbasis chip ATmega328. Arduino Uno memiliki 14 digital pin input / output (atau biasa ditulis I/O, dimana 14 pin diantaranya dapat digunakan sebagai output PWM antara lain pin 0 sampai 13), 6 pin input analog, menggunakan crystal $16 \mathrm{MHz}$ antara lain pin A0 sampai A5, koneksi USB, jack listrik, header ICSP dan tombol reset. Hal tersebut adalah semua yang diperlukan untuk mendukung sebuah rangkaian mikrokontroler

Salah satu polimer yang mudah dibentuk melalui electrospinning adalah Polyvinyl alcohol (PVA). PVA merupakan polimer yang sangat diminati karena pemanfaatannya yang sangat luas terutama dalam berbagai bidang farmasi, biomedis, dan bidang lainnya. PVA memiliki struktur kimia seperti yang ditunjukkan pada gambar 2 yang relatif sederhana dan masuk ke dalam kelompok hydroxyl. Monomer dari PVA yaitu vinyl alcohol tidak mempunyai bentuk stabil [7].

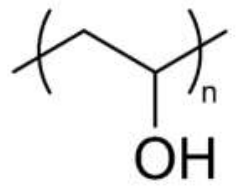

Gambar 2. Struktur molekul PVA [7]

PVA merupakan salah satu polimer yang memiliki berat molekul yang tinggi sehingga akan mengakibatkan viskositas yang tinggi juga ketika dilarutkan dalam air. Tingkat kelarutan dan kekentalan dari PVA tergantung pada tingkat polimerisasi dan tingkat hidrolisis. Tegangan permukaan larutan PVA bertambah seiring dengan bertambahnya tingkat hidrolisis, tapi hanya sedikit terpengaruh oleh tingkat polimerisasi [7].

\section{METODE}

Tahapan penelitian meliputi tahap persiapan, tahap perancangan dan pembuatan, serta tahap pengujian.

\section{a. Tahap Persiapan}

Tahap persiapan berupa persiapan bahan dan peralatan yang dibutuhkan. Beberapa bahan utama yang digunakan yaitu:

- Kaca akrilik (bodi electrospinning)

- Motor listrik dan besi (syringe pump dan collector)

- Trafo flyback, mikrokontroler, LCD display (high voltage)

- Bahan uji: PVA, aquades dan gelas kimia

b. Tahap perancangan dan pembuatan

Perancangan bodi electrospinning:

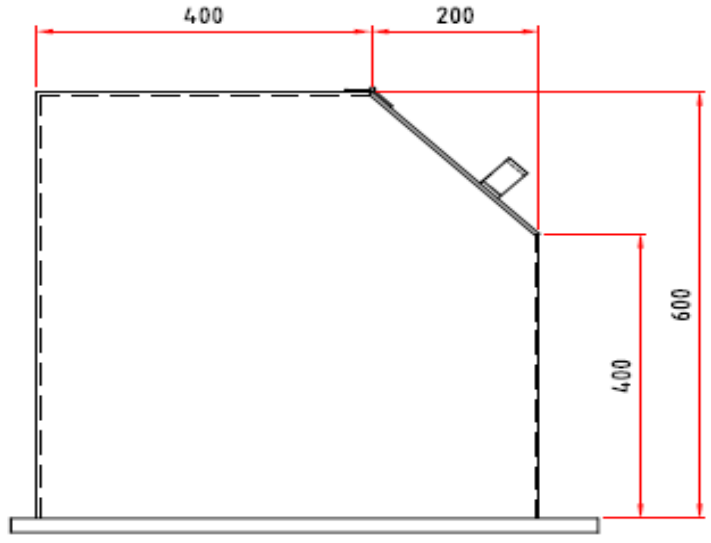

Gambar 3. Tampak saping bodi electrospinning 


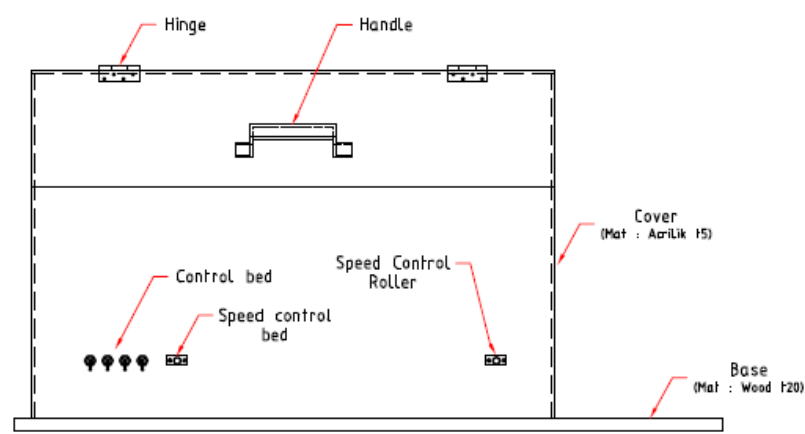

Gambar 4. Tampak depan bodi electrospinning Perancangan syringe punp:
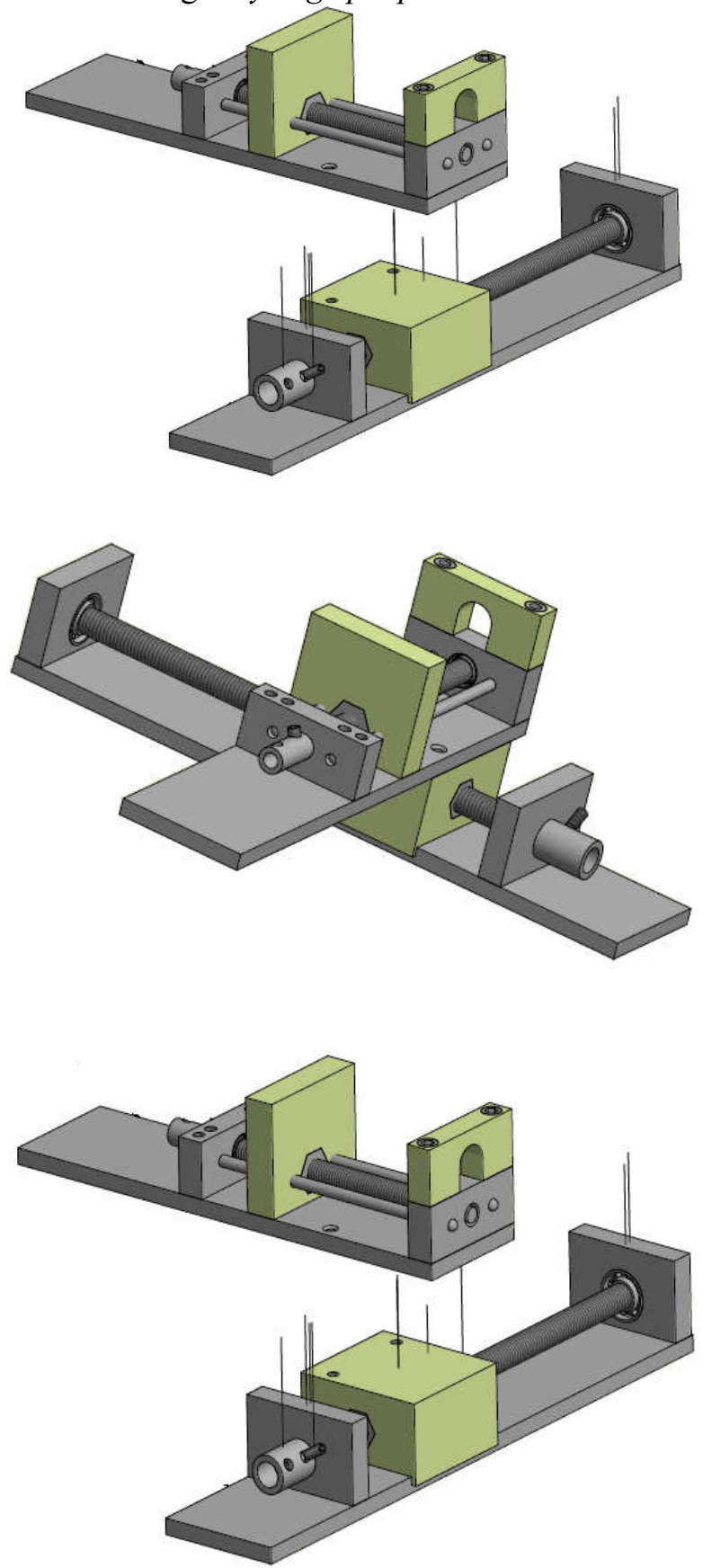

Gambar 5. Syringe pump electrospinning

Perancangan drum collector:
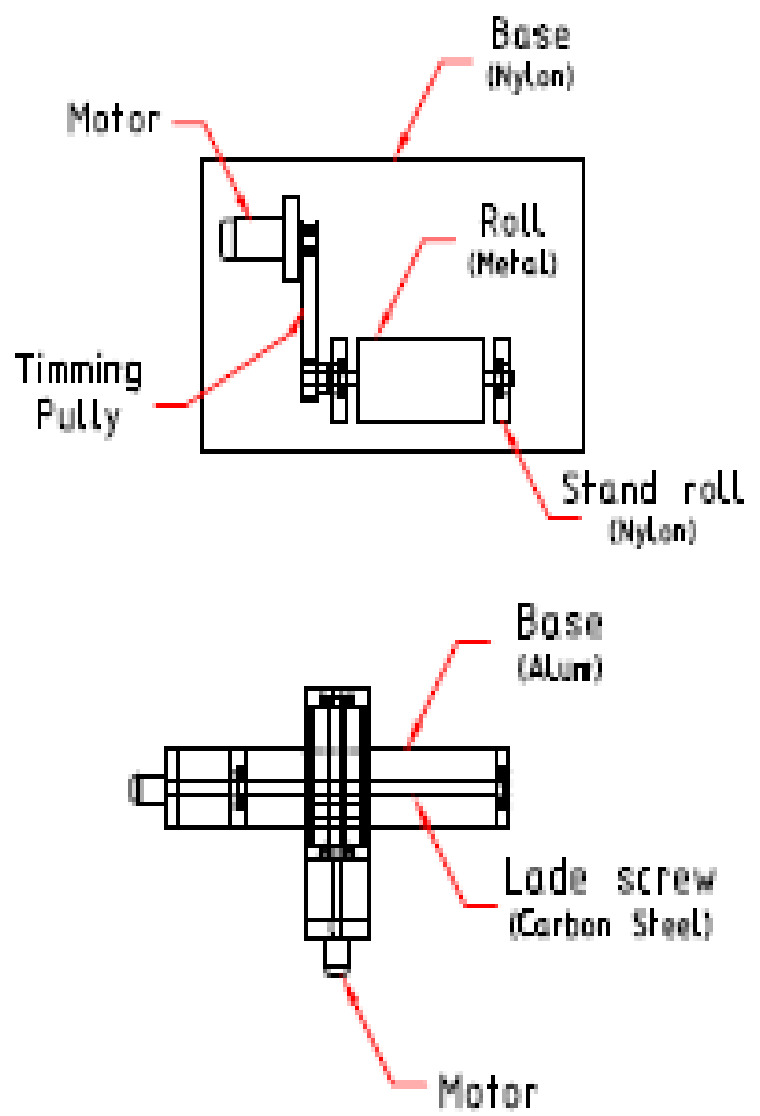

Gambar 6. Drum collector electrospinning

Perancangan high voltage power supply:

Diagram blok untuk pembangkit tegangan tinggi DC untuk sistem electrospinning:

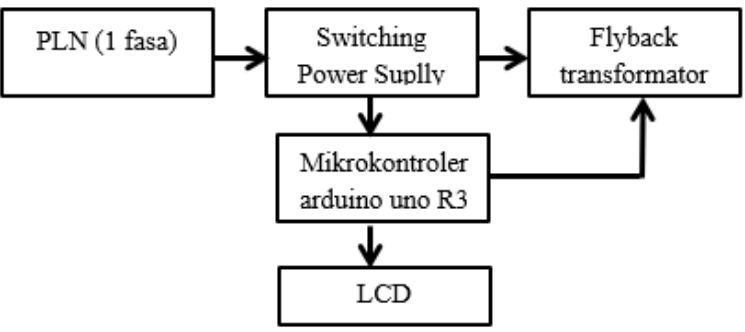

Gambar 7. Diagram high voltage DC Switching power supply merupakan bagian yang memberikan catu daya untuk Mikrokontroler, $L C D$, dan flyback transformator.

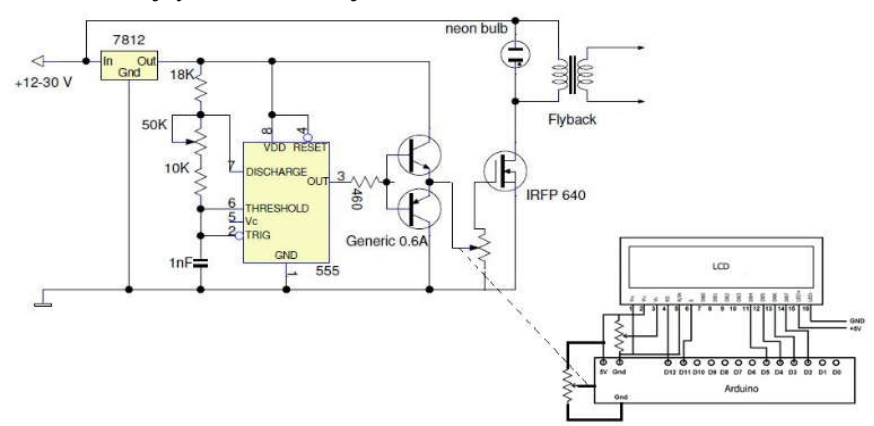

Gambar 8. Rangkaian high voltage DC

Program yang digunakan untuk High Voltage menggunakan Program Sketch Arduino. 


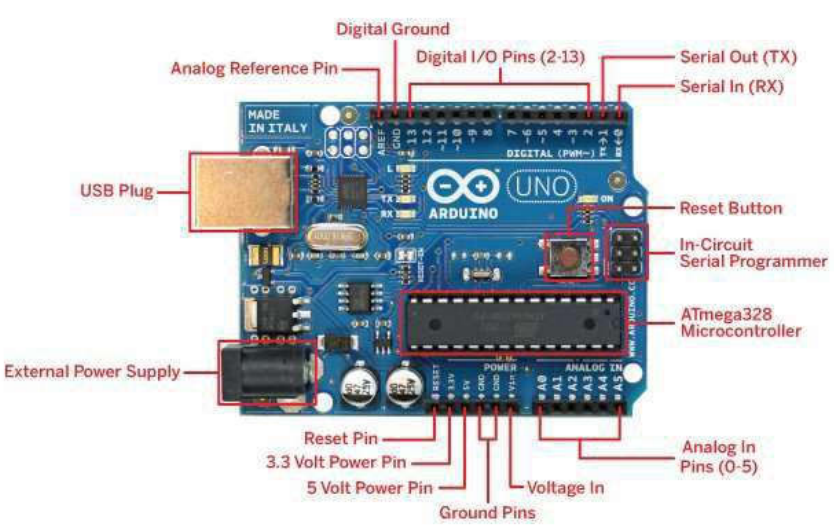

Gambar 9. Arduino Uno R3

Tabel 1. Spesifikasi Arduino Uno R3

\begin{tabular}{ll}
\hline Komponen & Keterangan \\
\hline Mikrokontroler & ATmega328 \\
Operasi Tegangan & 5 Volt \\
Input Tegangan & $7-12$ Volt \\
Pin I/O Digital & 14 \\
Pin Analog & 6 \\
Arus DC tiap pin I/O & $50 \mathrm{~mA}$ \\
Arus DC ketika 3.3V & $50 \mathrm{~mA}$ \\
Memori flash & $32 \mathrm{~KB}$ \\
SRAM & $2 \mathrm{~KB}$ \\
EEPROM & $1 \mathrm{~KB}$ \\
Kecepatan clock & $16 \mathrm{MHz}$ \\
\hline
\end{tabular}

\section{c. Tahap Pengujian}

Nanofiber dibuat menggunakan polimer PVA. Larutan PVA yang dibuat yaitu 10\%, dengan melarutkan 1,111 gram PVA ke dalam $10 \mathrm{ml}$ aquades yang sebelumnya telah dipanaskan pada suhu $90{ }^{\circ} \mathrm{C}$. Selanjutnya diaduk menggunakan magnetic hot plate stirrer hingga homogen. Selanjutnya larutan dimasukkan ke dalam suntikan, dan siap dilakukan proses electrospinning. Parameter electrospinning yaitu tegangan tinggi $15 \mathrm{kV}$ dan jarak jarum ke collector $15 \mathrm{~cm}$. Karakterisasi struktur morfologi nanofiber PVA menggunakan SEM. Perhitungan estimasi ukuran diameter nanofiber PVA menggunakan Software ImageJ.

\section{HASIL DAN PEMBAHASAN}

\section{a. Hasil pembuatan electrospinning}

Telah dilakukan rancang bangun dan pengujian sistem electrospinning dalam pembuatan nanofiber PVA seperti pada gambar berikut.

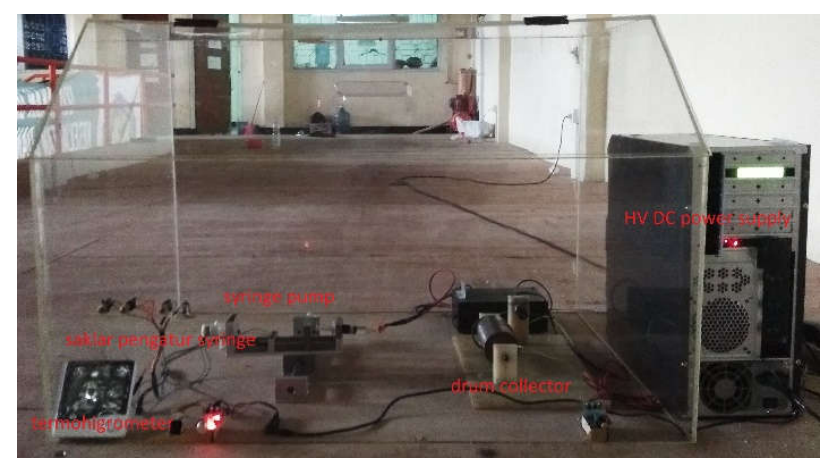

Gambar 10. Sistem electrospinning

Sistem electrospinning terdiri atas komponen utama berupa bodi (chamber), sumber tegangan tinggi DC (High voltage DC power supply), syringe pump dan drum collector. Bodi terbuat dari kaca akrilik sehingga tampak kuat, aman, transparan dan menghidari medan listrik (tegangan tinggi) yang mengalir ke luar bodi. Sumber tegangan tinggi DC dibuat dengan menggunakan trafo flyback, dengan tegangan keluaran dapat divariasikan dari $0-30 \mathrm{kV}$. Syringe pump mempunyai ukuran panjang $26 \mathrm{~cm}$, lebar 20, tinggi $7 \mathrm{~cm}$. Motor dc digunakan untuk menggerakan syringe pump ke kanan-kiri dan depan-belakang, pengontrolan kecepatan motor dc dapat dikontrol melalui driver motor dc. Mikro Arduino Uno R3 adalah papan pengembangan mikrokontroler yang berbasis chip ATmega328 yang digunakan untuk memprogram tampilan nilai tegangan yang keluar pada $L C D$, mengaktifkan dan menon-aktifkan tegangan tinggi.

\section{b. Hasil pembuatan nanofiber PVA}

Pengujian sistem electrospinning menggunakan larutan PVA $10 \%$ dengan parameter tegangan tinggi $15 \mathrm{kV}$, jarak jarum ke collector $15 \mathrm{~cm}$ dan diameter jarum suntik 0,4 $\mathrm{mm}$. Hasil pembuatan nanofiber dapat dilihat pada Gambar 11 berikut: 


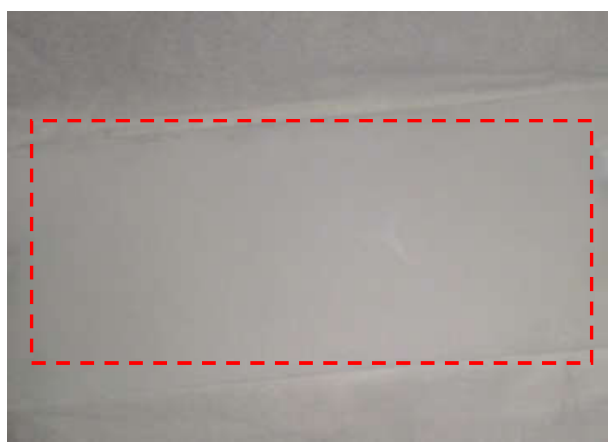

Gambar 11. Sampel nanofiber PVA

Tampak pada Gambar 11 nanofiber dapat terbentuk seperti membran berwarna putih halus, dan tampak homogen. Untuk memastikan nanofiber terbentuk, maka dilakukan karakterisasi menggunakan Scanning Electron Microscopy (SEM) dan perhitungan diameter menggunakan Software ImageJ.
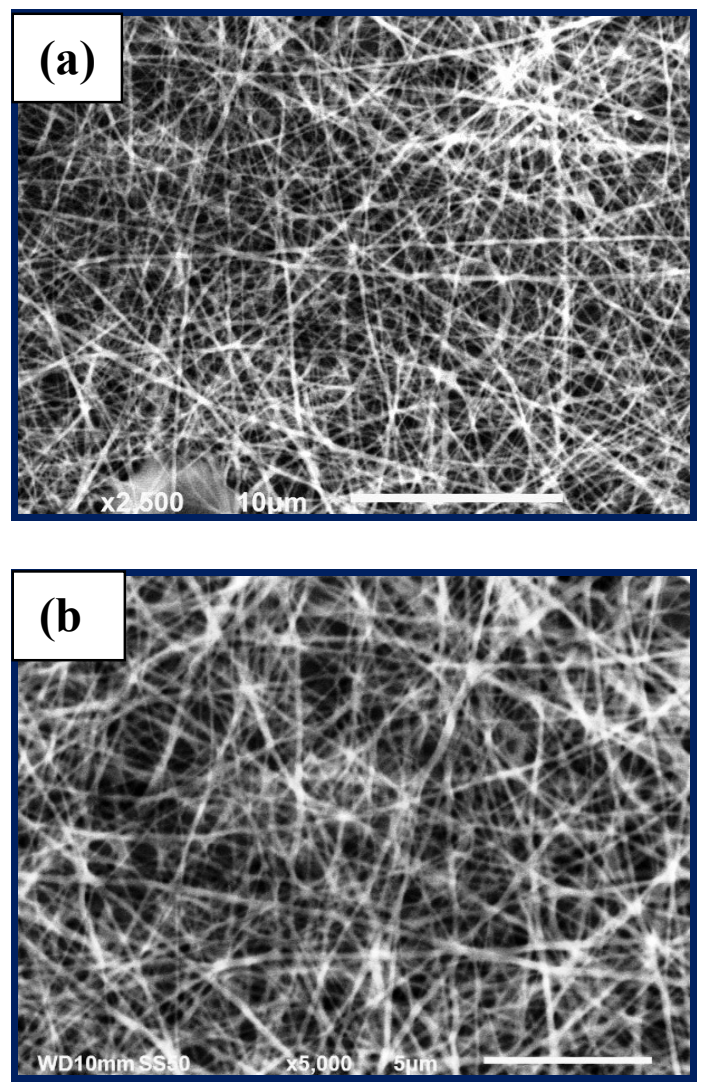

Gambar 12. Struktur morfologi nanofiber PVA perbesaran: (a) 2500x, (b) 5000x

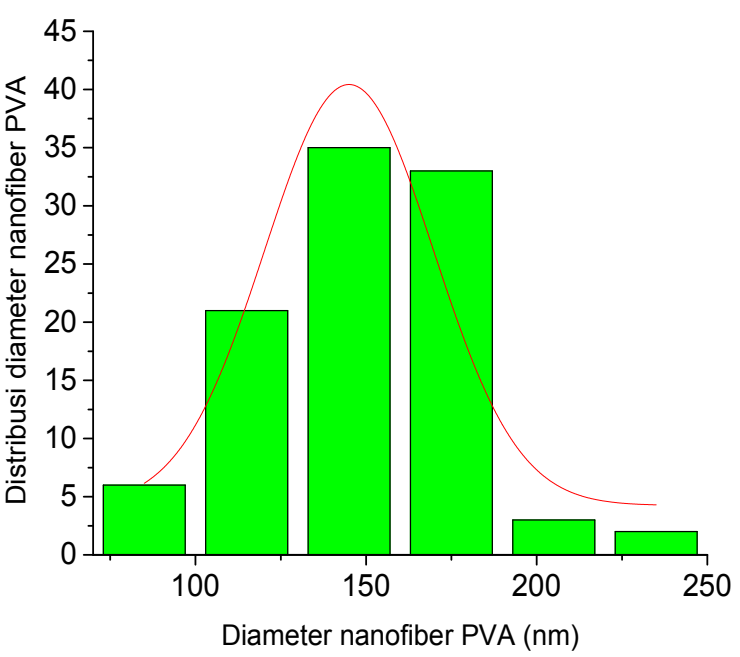

Gambar 13. Distribusi diameter nanofiber PVA

Pada Gambar 13 terlihat morfologi nanofiber yang terbentuk belum begitu homogen. Serat yang terbentuk tidak teratur (acak). Hal ini diduga adanya pengaruh larutan PVA yang dibuat kurang homogen, dan terlalu kental yaitu $10 \%$. Namun terlihat jelas bahwa ukuran diameter serat sudah mencapai ukuran nanometer. Ukuran rata-rata diameter nanofiber PVA yang terbentuk yaitu $(\mathbf{1 4 7 . 8 5} \pm \mathbf{2 4 , 7 3}) \mathbf{n m}$. Hasil menunjukkan bahwa sistem electrospinning yang dibuat berhasil mensintesis nanofiber.

\section{KESIMPULAN}

Dari hasil penelitian dan pembahasan dapat disimpulkan sebagai berikut:

a. Sistem electrospinning berhasil dibuat dengan bagian utama berupa bodi (chamber), sumber tegangan (High voltage dc power supply), syringe pump dan kolektor silnder (drum collector)

b. Hasil pengujian electrospinning dalam mensintesis nanofiber PVA menunjukkan ukuran rata-rata diameter nanofiber sebesar yaitu $(147.85 \pm 24,73) \mathrm{nm}$

\section{UCAPAN TERIMA KASIH}

Penulis mengucapkan terima kasih kepada rekan dosen Teknik Mesin Fakultas Teknik, Universitas Singaperbangsa Karawang, dan terima kasih yang sebesar-besarnya kepada Hibah Penelitian Dosen Pemula DIKTI atas dukungan financial. 


\section{DAFTAR PUSTAKa}

[1] Subbiah T. et.al. (2005). Electrospinning of Nanofiber, Journal of Applied Polymer Science, 2005, 96, 557-569.

[2] Mohan A. (2002). Formation and Characterization of Electrospun Nonwoven web, Textile Management and Technology, North Carolina State University.

[3] Lijun Yang, Wallace Woon-Fong Leung. (2011). Improvement of Dye Sensitized Solar Cells with Nanofiber-Based Anode, ASME 2011 International Mechanical Engineering Congress and Exposition (IMECE2011), November 11- 17, 2011, Denver, Colorado, USA.

[4] Pickett, A.N., (2012). Electrospinning Applications in Mechanochemistry and Multifunctional Hydrogel Materials.

[5] Junaedi \& Nurmayady, D., (2012). Perancangan Pembangkit Tegangan Tinggi Direct Current pada Sistem Electrospinning. ISSN 1979-2409.

[6] Ramakrishna, S., Fujihara, K., Teo, W.-E. \& Lim, T.-C., (2005). An Introduction to Electrospinning and Nanofibers. Singapore: World Scientific Publisher.

[7] Patachia, S., Valente, A. J., Papancea, A. \& Lobo, V. M., 2009. Poly (vinyl alcohol)[PVA]-based polymer membranes. New York: Nova Science Publisher.

[8] Toto Sugiarto, Dwi Sudarno Putra, Wawan Purwanto. (2017) Analysis on the role of engine coolant temperature in gasoline engine. VANOS Journal of
Mechanical Engineering and Education, 2(2) $145-142$. 